\title{
Distribution of Productive Zakat for Reducing Urban Poverty in Indonesia
}

\author{
Nur Kholis ${ }^{a}$, Mugiyati ${ }^{\mathbf{b}}$, ${ }^{\mathrm{a}, \mathrm{b}}$ Fakultas Ekonomi dan Bisnis Islam, UIN Sunan \\ Ampel Surabaya, Indonesia, Email: ${ }^{a}$ nurkholis@uinsby.ac.id, \\ bmugiyati@uinsby.ac.id
}

Productive zakat is a strategic mechanism to help alleviate poverty. This study aims to explore the mechanism by which BAZNAS manages productive zakat in an attempt to help alleviate poverty in Indonesia. This study uses a qualitative exploratory approach. Documentary data pertaining to zakat distribution to mustahīq in the urban poor Surabaya was collected from the East Java BAZNAS office. Several interviews with the leaders of this office were also conducted to capture their views on the management of productive zakat. The results showed that to reduce the poverty of the urban poor, the BAZNAS applies a strategic distribution of productive zakat implemented through (1) a revolving capital loan to increase venture capital of the mustahiq members of MSMEs run under the qard al-hasan contract, and (2) providing work equipment for starting or developing businesses. These mechanisms were effective in helping the poor for starting and expanding their business, hereby improving their wellbeing. It is suggested that amil zakat may increase the allocation of zakat distribution for productive purposes, rather than for one stop consumption. This study expands the understanding of the currently developed approach to zakat management and provides sound good practices in reducing poverty.

Keywords: Distribution of Productive Zakat, Poverty Reduction, Urban Poor.

\section{Introduction}

Islam views poverty not only as one that can endanger the faith, moral and mind, but also as calamity and disaster that must be seriously resolved. An effort to reduce poverty is the creation of a mechanism by which the wealth of the haves is channelled to the entitled recipients. Zakat is an official institution in Islam directed to create equality and justice in the community in order to improve their standard of living (Hafidhuddin, 2007, p. 104) and to escape from the poverty line (Adebayo, 2011; Ahmed, 2004). In Indonesia, an individually and directly handing over of zakat to the mustahīq or to an amil of religious figures and socio-religious organisations has been common practice due to the view that zakat is a Godly personal matter and the 
influence of classical figh (Islamic jurisprudence), and this is mostly in a consumptive way (Mubasirun, 2013).

Previous studies report the distribution of zakat both for consumptive and productive purposes. Research on the consumptive approach includes Harisah \& Zainulloh (2019) who reported that in Sampang the practice of zakat distribution was consumptive to meet the basic need of the recipients. Riadi (2020) also reported that the distribution of zakat by the National Amil Zakat Agency (BAZNAS) Mataram were in many forms, yet in terms of the empowerment of mustahiq was still less optimal, e.g., in providing capital and a revolving fund, suggesting that it still focused on a consumptive rather than a productive approach. Further research by Thalib, Irwan, \& Ro'is (2017) was aimed at managing zakat to overcome poverty in the City of Bima and found that the distribution of zakat was still consumptive so that it has not been able to bring about a significant change in the recipient welfare.

Studies dealing with the distribution of zakat in a productive way include Haidir (2019) who questions whether providing venture capital by BAZNAS could lessen poverty in Yogyakarta City and found that it did reduce poverty, increase income and give birth to new entrepreneurs. Wiradifa \& Saharuddin (2018) found zakat distribution in BAZNAS South Tangerang City in three forms: traditional consumptive, traditional productive, and creative productive. Hidayati et al. (2020) analysed the strategies of zakat distribution in Jombang in a productive way under the name of "Jombang Makmur," covering skills training for SMEs, working tools assistance to start/develop a business, direct capital grants, revolving capital assistance to MSMEs, and shariah business financing in the form of capital loans to SMEs.

Several research studies specifically examine the relationship between productive zakat and poverty alleviation. For example, Andriyanto (2011) conducted research on the management and distribution of zakat, infāq and şadaqãh (ZIS) funds for poverty alleviation in Central Java, but did not focus on the urban poor and also through the Indonesian Zakat House, which is not a regional BAZNAS. Similarly, Kholiq's research (2012) examines the role of several amil zakat institutions in reducing poverty in the city of Semarang through a capital loan assistance program, but not a revolving capital loan. More recent studies include Sari et al. (2019) which found that zakat reduces poverty and that it helps the poor escape from the poverty line.

Previous studies indicate a variety of mechanisms for the distribution of productive zakat and that the productive zakat has positive impact on poverty alleviation. However, the kinds of programs designed by BAZNAS for poverty reductions vary across agencies. This article, therefore, aims to elaborate practices of productive zakat distribution in its attempt to reduce poverty traps of the urban poor community. The study took place at the East Java BAZNAS in Surabaya City, Indonesia, as a case analysis. The study broadens the understanding of the zakat management model and approach. In addition, it suggests good practices in programs and roles that zakat institutions can play in reducing poverty. 


\section{Literature Review}

The Qur'an uses several terms for the meaning of zakat, namely: zakat (QS. 2:110), şadaqãh (alms) (QS. 9:103), infāq (spending simply to please Allah) (QS. 17:100), dan haq (right) (QS. 6:141). These four terms are often used interchangeably to mean similar thing. Zakat is called infāq (QS. 9:34) because it is the surrender of property for the virtues commanded by Allah Almighty. It is called alms (QS. 9:60) because one of the main purposes of zakat is to get closer (taqarub) to Allah Almighty. Zakat is called a right because it is a definite decree that must be given to the entitled receivers (mustahīq) (Kemenag RI, 2013, p. 20).

According to the major Sunni madhab (school of thought), Hanafi, Maliki, Shafi'i and Hanbali define zakat slightly differently, yet for the same meaning. Hanafiyah scholars define zakat as specifying a portion of property in accordance with Sharī $a h$. The Maliki School views it as the withdrawal of portion of a specific property that has reached nișāb (the minimum amount a Muslim must have before being obliged to give zakat) to the entitled recipients. Syafi'iyah scholars define zakat as an expression of the release of property in a special way. The Hanbaliyah school defines zakat as a right that must be removed from a specific property for a specific group (Al-Zuhayly, 2000, p. 3).

In the early Islamic history, zakat was only required on five types of assets: (i) gold and silver; (ii) commercial goods; (iii) self-feeding animals such as camels, cows and goats; (iv) plants and: (v) metal goods and treasure. The types of assets that must be taken as zakat continue to develop along with the development of current patterns of economic activity. According to contemporary scholars such as Yusuf Qaradawi, the assets of obligatory zakat are divided into nine groups: (i) livestock; (ii) gold and silver including dinars and dirhams and other currencies; (iii) trades; (iv) agricultural products (including honey, productive animal, and agricultural land); (v) mining and marine products; (vi) investment for industries; (vii) buildings; (viii) services and professions and: (ix) shares and bonds (Qaradawi, Kahf, \& Siddiqui, 2011, p. 235)

One of the aims of zakat is to improve the economic condition of the entitled recipients called mustahìq, covering eight categories: faqir (the poor), miskin (the needy), amil (zakat collectors), muallaf (the new converts to Islam), riqab (freedom of slaves), gharimin (the heavily indebted), sabillilläh (strivers in the cause of Allah), and ibn sabïl (wayfarers) (QS. 9:60) (Departmen Agama RI, 2010). Zakat is an Islamic teaching that aims to realise social justice through the mechanism of wealth distribution from the rich to the poor. Islam requires that wealth should not only spin among the rich. Normatively, Islam views that in the wealth of the rich there is the right of the poor. Thus, the true zakat is the practice of worship in Islam which is in line with efforts to alleviate and overcome poverty (Qaradawi et al., 2011, p. 425). 
The contemporary progressive thoughts in zakat have resulted in the establishment of BAZNAS under Presidential Decree No. 8 of 2001 which has the task and function of collecting and distributing zakat, infāq and şadaqãh (ZIS) at the national level. It is a non-structural government institution that is independent and accountable to the President through the Minister of Religious Affairs. Ten years later the Indonesian Government issued Law Number 23 Year 2011 on Zakat Management to strengthen the role and function of BAZNAS (Baznas, 2019). The operation of BAZNAS is based on Islamic law, trust, benefit, justice, legal certainty, integrity, and accountability (Lamuri, 2016).

Through zakat institutions, Islam stands to provide protection for the interests of the poor by instilling moral responsibility to the rich to pay attention to the poor (Kemenag RI, 2013, p. 10). Thus, zakat becomes one of the alternative solutions in building the ummah economy to improve their living standards and alleviate poverty (Mkuu \& Yusoff, 2017; Nadzri, AbdRahman, \& Omar, 2012; Shaikh \& Ismail, 2017) while creating a climate of solidarity among humans. To realise this goal, help alleviate poverty and eliminate social inequalities, there needs to be a professional management of zakat (Sadili, 2003, p. 93). The shift from consumptive to productive distribution of zakat is also necessary, e.g., supporting education, provision of low-cost housing, and economic development (Amarudin, 2019; Ardiani, 2020; Wahab \& Rahman, 2011; Wicaksono, 2019). According to Mufraini (2006) there are two kinds of distribution of zakat for productive purpose, namely traditional productive that will create jobs for the poor, e.g., cows, and creative productive such as giving capital for entrepreneurs.

Zakat collection by BAZNAS has experienced a positive development, and even the institution has been considered efficient and effective due to the implementation of a modern professional management system. According to the Director of Operation of BAZNAS, the total potential of zakat in Indonesia is IDR280 trillion (Susanti, 2019). However, its annual collection is far less than the targeted. According to BAZNAS statistics, in 2019 the average growth of zakat accumulation in the last five years was $25.72 \%$. In 2015 the growth was $10.6 \%$ amounting a total of IDR3,65 trillion and in 2019 was $26 \%$ representing a total of IDR 10,22 trillion (Baznas, 2020, pp. 7-8). However, there is a growth discrepancy among provincial level BAZNAS. In response to this, continuous socialisation activities should be carried out so that zakat and its management through legal institutions can gain bigger public trust.

An effort has been made to maximise zakat distribution including using current information technology. For example, Asa (2019) designed a program using algorithm C4.5 for smooth and correct distribution of zakat. Similarly, Afriyenis, Rahma, \& Aldi (2018) devised a program using information and technology such as an SMS centre and social media to support better distribution of Zakat in Padang. Andiani, et al. (2018) analysed various strategies by which BAZNAS collects and distributes zakat and suggested that sharia banking was the most strategic partner. However, recent evaluation shows that the distribution of national zakat was very effective that is around 90 percent of the collected (Bahri \& Khumaini, 2020). 


\section{Methods}

The purpose of this study was to analyse the implementation of productive zakat management in reducing urban poverty. To meet this objective, the researcher used qualitative research with an exploratory method. This study took place in the East Java BAZNAS branch located in Surabaya, Indonesia. Data collection used document review techniques (Bretschneider, Cirilli, Jones, Lynch, \& Wilson, 2017) and interviews. Documents reviewed were printed and viewed electronically covering institutional reports, meeting notes, and customer records. Interviews were conducted with the management team of East Java BAZNAS determined purposefully to uncover the implementation of productive zakat in relation to reducing urban poverty. The management teams are figures assumed to have complete information related to the theme of this study. In addition, as many as ten recipients of zakat of various programs were interviewed to capture their views about the zakat benefits. Semi-structured interface interviews were conducted in accordance with the general practice of qualitative research using the interview method (Seidman, 2019, pp. 11-12). The brief interview guide was created to direct the focus of interviews, containing global questions about how productive zakat management has been carried out in order to help reduce urban poverty. Data gathered was analysed using a model of descriptive analysis, including data reduction, data display, and conclusion drawing (Miles, Huberman, \& Saldaña, 2019, p. 69).

\section{Results and Discussion}

The birth of the East Java BAZNAS branch was based on Zakat Law No. 23 of 2011. It is a step of the institutional change from a merely religious institution to a non-structural government organisation. Its establishment would reduce the tasks and work of the provincial government, especially in the social sector, such as poverty alleviation programs. The synergy of these agencies would result in the effective strategy for poverty reduction, particularly in the urban community.

The yearly potential zakat fund in East Java was around IDR15 trillion (Jajeli, 2017) compared to that nationally amounting to IDR233 trillion (Setiawan, 2019). It was expected that East Java BAZNAS contributes around IDR500 billion yearly (Rozack, 2018), but its annual realisation is as low as 1\%, amounting IDR5.09 billion (Canggih, Fikriyah, \& Yasin, 2017). As such the realisation was mostly obtained from the zakat of civil servants (PNS) in the East Java Provincial Government. The civil servants are obliged to spare $2.5 \%$ of their monthly incentives rather than their main salaries for paying professional zakat.

The considerable funds collected requires a strategy of professional and innovative utilisation of zakat which would lead to a greater impact in improving the welfare of the poor community as well as eradicating poverty (Arif, 2017; Ariyani, 2016). Productive utilisation of zakat needs to be supported to the maximum. However, according to the BAZNAS management, the 
utilisation of zakat funds for productive economic programs at East Java BAZNAS still depends on the allocation for other programs. For example, when a humanitarian fund is low, the proportion given to productive economic activities will be high. Conversely, when the needs and allocations for humanitarian funds are high, the allocation to the productive economy is low. However, in subsequent years, allocations for productive economic programs tend to be stable at $10 \%$ of the annually collected zakat.

East Java BAZNAS collects ZIS funds and allocates them for several core programs, including East Java Smart (scholarships for elementary to higher education students), East Java Healthy (health services for the poor community), East Java Cares (assistance for disaster), and East Java Taqwa (financial support for dakwah programs). The specifically designed program for poverty alleviation and the transformation of mustahìq to muzakki status is East Java Makmur (Prosperity), which is implemented in two approaches (Baznas Jatim, 2020).

The first approach is the provision of work equipment. It is an assistance program by freely giving work tools to mustahiq for starting or developing a business, such as an air compressor for tire patches, storefronts, raw craft materials, and selling carts for street vendor. In 2016, the empowerment program for Surabaya poor community with the scheme of work tools assistance reached about IDR5 billion for 3,947 micro enterprises which spread in East Java regions. In Surabaya area alone, there are about 493 micro businesses supported by this program.

Giving various work equipment is appropriate due to skill diversity among the poor. In addition, with work tools people can earn money to free themselves from poverty traps. All of the recipients agree that this approach is useful in helping them start new business activity. Research on zakat in relation to reducing poverty concludes that enhancing the distribution of zakat for productive type would increase its impact in alleviating poverty (Ardiani, 2020; Saad \& Abdullah, 2014; Wicaksono, 2019). Providing working tools could also be considered as a better mechanism than giving unconditional cash. Some studies show that although providing unconditional cash transfer in the short term is useful to the poor, it has led to an increased dependency on government assistance, (Akib \& Risfaisal, 2016) an expectation to more assistance, (Setyawardani, Paat, \& Lesawengen, 2020) reduced productivity, and increased consumptive behaviour.

The second model is revolving fund aid, amounting to IDR600 million every year and has been operating for about two decades, starting in 2006. It is a kind of a productive zakat distribution using qard hasan financing mechanism. This aid is the provision of capital loans without interest for micro, small and medium enterprises (MSMEs) in the East Java region, accompanied by business assistance and religious mentors for activities in groups as well as channelling and coaching partners. 
This program is aimed at avoiding an interest system emanating from credit loans and to break the trap of moneylenders widespread amidst the economically disadvantaged people. With the revolving capital aid, the business of mustahīq can be expected to develop. From their business profit, mustahiq can be trained in infaq (charity giving) in addition to develop their sense of responsibility for the loan funds received. Mustahīq who receive revolving capital loan must meet certain requirements; first, they must form a group with 5-10 people who act honestly in running their business; second, their business has been running for at least 6 months and prospective, and third, they are willing to be coached and supervised by the BAZNAS. The training provided for the receivers usually covers business management and development.

The revolving capital loans are distributed in three stages. For micro business, for example, the first instalment is IDR1.000.000, the second IDR2.000.000, and the third IDR3.000.000, for each mustahiq. After the third stage, East Java BAZNAS conducts an assessment of the mustahi $q$ business progress. When the mustahīq business has developed, the revolving capital assistance is stopped and allocated to other mustahiq. They are obliged to return the loan funds to amil gradually within eleven months starting from the second month after receiving revolving funds. Nominal return instalments are flat/fixed every month and accompanied by paying infāq or şadaqãh with the amount being unspecified. This mechanism is to train mustahì to become accustomed to şadaqãh. Previously, the fund aid provided by East Java BAZNAS was in the form of grant. But this grant program turned out to result in the borrowers being irresponsible to the business they develop. Consequently, the capital given was often used up unnecessarily. A non-interest loan system has made entrepreneurs more responsible for their business as they are obliged to pay back the debt. A revolving fund loan system can help many MSMEs develop even better.

The fact that East Java BAZNAS provides work equipment and revolving capital loans can be interpreted to have implemented a "zakat budget surplus system." According to Mas'ud and Muhammad (2005, p. 34) the zakat budget surplus system is the total amount of zakat revenue greater than the total distribution of zakat. In other words, zakat funds collected are not distributed in total; some are distributed and the remainder is for savings which would be used as a source of funding for productive economy. This pattern has three models: zakat certificate, in kind and revolving fund. Zakat certificate is intended as a substitute for handover of zakat cash, where zakat funds by amil zakat institutions are invested in industries allowing for absorbing labour from the poor. If they can work, they will get a steady source of income. The profits from the industry can be channelled again to the eight asnáf (Nafiah, 2015).

The in-kind model is a zakat management system where the allocation of zakat funds distributed to mustahīq is not in the form of money but in the form of production tools such as machinery or livestock needed by economically weak people who have the desire to be productive, both for those who just initiate a business and who want to expand their current business. The revolving fund type is implemented by positioning zakat funds as loan funds that 
must be returned either with or without profit sharing. The spirit of this system is to encourage the poor to make a serious effort in their businesses. By this system, in the following years, they would no longer be recipients of zakat, but rather the givers of zakat.

Several studies have found the effectiveness of implementing revolving fund patterns in improving the welfare of recipients, at least its ability to meet the basic needs of mustahi $q$ such as increased income, productivity, and food sufficiency (Ningrum, 2016). Research using RoI (Return on Investments) analysis to see whether the initial capital of revolving loan funds yields profits found that revolving funds have been effective in providing benefits of loan recipients (Hidayat \& Rusdarti, 2016). International research into the implementation of revolving funds in rural communities has found that revolving funds have a positive impact on poverty reduction (Davidson \& Ørskov, 2010).

It appears that the use of a revolving fund pattern in the distribution of productive zakat by the East Java BAZNAS can be said to be appropriate and effective. It is expected that the use of productive revolving funds can help improve the economy of mustahiq and the economy of the weak community and help the government in improving the country's economy. Productive zakat has a significant influence in various aspects of the ummah lives, including in their economy, morality, and well-being (Sulaiman, 2003). In addition, there is generally a positive correlation of zakat and the improvement of the poor wellbeing (Rini, Fatimah, \& Purwanti, 2020).

\section{Conclusions}

The management of zakat in Indonesia has shifted from traditional to modern and from consumptive to productive. The potential of zakat in Indonesia is huge due to the majority of the population being Muslim. In Islam, zakat is an institution that distributes a portion of the wealth of the rich to the entitled. In this context, zakat denotes a double dimension: vertical worship (obedience to God) and horizontal worship (participation in improving human quality). BAZNAS was established to collect and distribute zakat of Indonesian Muslims with a more productive approach, so that it has the ability to improve the welfare of the community. In distributing productive zakat related to poverty alleviation East Java BAZNAS applies two main models: the provision of work equipment to mustahiq and revolving capital loans both for mustahi $q$ who are just running a business and who need venture capital to improve their business. The productive distribution of zakat carried out by East Java BAZNAS is effective in improving the welfare of mustahi $q$ and reducing their poverty level. The findings of this study are consistent with those from previous empirical studies that were done elsewhere, e.g., Ayuniyyah, Pramanik, \& Saad (2018), Kasri (2016), and Rini, Fatimah, \& Purwanti (2020). This study suggests that there could be another better mechanism in distributing zakat fund for a maximum impact on the recipients. These good practices in the productive distribution of zakat may be implemented by other zakat agencies. 
International Journal of Innovation, Creativity and Change. www.ijicc.net

Volume 15, Issue 3, 2021

\section{REFERENCES}

Adebayo, R. I. (2011). Zakat and Poverty Alleviation: A Lesson for the Fiscal Policy Makers in Nigeria. 7(4), 25-42.

Afriyenis, W., Rahma, A. A., \& Aldi, F. (2018). Implementasi Teknologi Informasi dan Komunikasi dalam Zakat untuk Meningkatkan Kesejahteraan Masyarakat Miskin. JEBI: Jurnal Ekonomi dan Bisnis Islam, 3(2), 227-236.

Ahmed, H. (2004). Role of Zakah and Awqaf in Poverty Alleviation (Occasional Paper). Jeddah: Islamic Development Bank, Islamic Research and Teaching Institute.

Akib, I., \& Risfaisal, R. (2016). Bantuan langsung tunai. Equilibrium: Jurnal Pendidikan Sosiologi, 3(2), 126-135. doi: https://doi.org/10.26618/equilibrium.v3i2.283

Al-Zuhayly, W. (2000). Zakat kajian berbagai mazhab (Effendy \& B. Fananny, Trans.). Bandung: PT Remaja Rosdakarya.

Amarudin, M. (2019). Optimalisasi Dana Zakat Di Indonesia (model Distribusi Zakat Berbasis Pemberdayaan Ekonomi). EKSYAR: Jurnal Ekonomi Syari'ah \& Bisnis Islam, 6(01), 1-13. Retrieved from https://staimtulungagung.ac.id/ejournal/index.php/Eksyar/article/view/380

Andiani, K., Hafidhuddin, D., Beik, I. S., \& Ali, K. M. (2018). Strategy of BAZNAS and Laku Pandai for Collecting and Distributing Zakah in Indonesia. Al-Iqtishad: Jurnal Ilmu Ekonomi Syariah, 10(2), 417-440.

Andriyanto, I. (2011). Strategi pengelolaan zakat dalam pengentasan kemiskinan. Walisongo: Jurnal Penelitian Sosial Keagamaan, 19(1), 25-46. doi: 10.21580/ws.19.1.211

Ardiani, N. R. (2020). Optimalisasi Distribusi Zakat Pada Tiga Lembaga Amil Zakat Nasional Di Surabaya (Master Thesis, Universitas Airlangga). Universitas Airlangga, Surabaya. Retrieved from http://repository.unair.ac.id/95140

Arif, M. (2017). Zakat as a Mode of Poverty Alleviation. International Journal of Economics \& Management Sciences, 06(06). doi: 10.4172/2162-6359.1000473

Ariyani, N. (2016). Zakat as a Sustainable and Effective Strategy for Poverty Alleviation: From the Perspective of a Multi-Dimensional Analysis. International Journal of Zakat, 1(1), 88-106. doi: 10.37706/ijaz.v1i1.9

Asa, R. S. (2019). Identifikasi Penyaluran Zakat Menggunakan Algoritma C4.5 (Studi Kasus di BAZNAS Kabupaten Agam. Jurnal Sains dan Informatika, 5(1).

Ayuniyyah, Q., Pramanik, A. H., \& Saad, N. (2018). Zakat for poverty alleviation and income inequality reduction: West Java, Indonesia. 4(1), 16.

Bahri, E. S., \& Khumaini, S. (2020). Analisis Efektivitas Penyaluran Zakat pada Badan Amil Zakat Nasional. Al Maal: Journal of Islamic Economics and Banking, 1(2), 164-175. doi: 10.31000/almaal.v1i2.1878

Baznas. (2019). Profil-Badan Amil Zakat Nasional. Retrieved from https://baznas.go.id/profil

Baznas. (2020). National zakat statistic. Jakarta: Baznas - Sub Divisi Pelaporan. Retrieved from https://pid.baznas.go.id/wp-content/uploads/2020/09/STATISTIK-ZAKATNASIONAL-2019.pdf 
International Journal of Innovation, Creativity and Change. www.ijicc.net

Volume 15, Issue 3, 2021

Baznas Jatim. (2020, December). BAZNAS Jawa Timur - Mengelola Zakat Anda Amanah dan Profesional. Retrieved December 21, 2020, from https://baznasjatim.or.id

Bretschneider, P. J., Cirilli, S., Jones, T., Lynch, S., \& Wilson, N. A. (2017). Document Review as a Qualitative Research Data Collection Method for Teacher Research. In SAGE Research Methods Cases. London: SAGE Publications. Retrieved from https://www.doi.org/10.4135/9781473957435

Canggih, C., Fikriyah, K., \& Yasin, A. (2017). Potensi dan realisasi dana zakat Indonesia. AlUqud: Journal of Islamic Economics, 1(1), 14-26. doi: 10.26740/al-uqud.v1n1.p14-26

Davidson, G., \& Ørskov, E. R. (2010). The revolving fund system in sustainable community development. The 5th International Seminar on Tropical Animal Production, 11-18. Yogyakarta, Indonesia: Gajahmada University. Retrieved from https://journal.ugm.ac.id/istapproceeding/article/view/30402

Departmen Agama RI. (2010). Al-Qur'an dan terjemahan. Bandung: CV Diponegoro.

Hafidhuddin, D. (2007). Agar Harta Berkah dan Bertambah: Gerakan Membudayakan Zakat, Infak, Sedekah, dan Wakaf. Jakarta: Gema Insani.

Haidir, M. S. (2019). Revitalisasi Pendistribusian Zakat Produktif sebagai Upaya Pengentasan Kemiskinan di Era Modern. Muqtasid: Jurnal Ekonomi dan Perbankan Syariah, 10(1), $57-68$.

Harisah, H., \& Zainulloh, Z. (2019). Praktik Distribusi Zakat Konsumtif Tradisonal Di Karang Penang Sampang. Ulumuna: Jurnal Studi Keislaman, 5(1), 130-145. doi: 10.36420/ju.v5i2.3642

Hidayat, A. R., \& Rusdarti, R. (2016). Efektivitas program dana bergulir bagi perkembangan usaha koperasi di kota Semarang. Economics Development Analysis Journal, Vol. 5, No. 2, 115-122. doi: 10.15294/edaj.v5i2.22024

Hidayati, A., Chamim, M., Huda, S., \& Haryanti, P. (2020). Peta Distribusi Zakat, Infak, Dan Sedekah (Studi Developmental pada BAZNAS Kabupaten Jombang). ZISWAF : Jurnal Zakat Dan Wakaf, 7(1), 86-99. doi: 10.21043/ziswaf.v7i1.7457

Jajeli, R. (2017). Potensi zakat di Jatim Rp 15 t, ini tantangan lembaga amil zakat. Detiknews. Retrieved from https://news.detik.com

Kasri, R. A. (2016). Effectiveness of Zakah Targeting in Alleviating Poverty in Indonesia. AlIqtishad: Journal of Islamic Economics, 8(2), 169-188. doi: 10.15408/aiq.v8i2.3005

Kemenag RI. (2013). Membangun perspektif pengelolaan zakat nasional. Jakarta: Kemenag RI.

Kholiq, A. (2012). Pendayagunaan zakat, infak dan sedekah untuk pemberdayaan ekonomi masyarakat miskin di kota semarang. Jurnal Riptek, 6(1), 1-7.

Lamuri, A. B. (2016). Membangun paradigma baru pengelolaan zakat kota Palu dalam perspektif UU Nomor 23 tahun 2011. Al-Maslahah Jurnal Ilmu Syariah, 12(2), 331350. doi: 0.24260/almaslahah.v12i2.573

Mas'ud, R., \& Muhamad. (2005). Zakat \& kemiskinan: Instrumen pemberdayaan ekonomi umat. Yogyakarta: UII Press. 
International Journal of Innovation, Creativity and Change. www.ijicc.net

Volume 15, Issue 3, 2021

Miles, M. B., Huberman, A. M., \& Saldaña, J. (2019). Qualitative data analysis: A methods sourcebook (4th ed.). Thousand Oaks, CA: SAGE Publications.

Mkuu, K. M., \& Yusoff, M. E. B. (2017). Zakat Institution. An Alternative for Poverty Alleviation in Zanzibar. European Journal of Business and Management, 9(14), 5763.

Mubasirun, M. (2013). Distribusi Zakat Dan Pemberdayaan Ekonomi Umat. INFERENSI, 7(2), 493. doi: 10.18326/infs13.v7i2.493-512

Mufraini, M. A. (2006). Akutansi dan Manajemen Zakat. Jakarta: Kencana.

Nadzri, F. A. A., AbdRahman, R., \& Omar, N. (2012). Zakat and poverty alleviation: Roles of zakat institutions in Malaysia. International Journal of Arts and Commerce, 1(7), 6172.

Nafiah, L. (2015). Pengaruh pendayagunaan zakat produktif terhadap kesejahteraan mustahiq pada program ternak bergulir baznas kabupaten Gresik. Jurnal EL-Qist, 5(1), 929-942. doi: 10.15642/elqist.2015.5.1.929-942

Ningrum, R. T. P. (2016). Penerapan manajemen zakat dengan sistem revolving fund models sebagai upaya efektifitas penyaluran zakat produktif (studi pada lembaga manajemen infaq Madiun). El-Wasathiya: Jurnal Studi Agama, 4(1), 1-21. Retrieved from http://ejournal.kopertais4.or.id

Qaradawi, Y., Kahf, M., \& Siddiqui, I. (2011). Fiqh al-zakah: A comprehensive study of zakah regulations and philosophy in the light of the Qur'an and Sunnah. Petaling Jaya, Selangor: Islamic Book Trust.

Riadi, S. (2020). Strategi Distribusi Zakat dan Pemberdayaan Mustahik: Studi Kasus Baznas Kota Mataram. Schemata: Jurnal Pasca Sarjana IAIN Mataram, 9(1), 125-136. doi: 10.20414/schemata.v9i1.2264

Rini, R., Fatimah, F., \& Purwanti, A. (2020). Zakat and Poverty: An Indonesian Experience. International Journal of Innovation, Creativity and Change, Vol. 10, No. 11, 12.

Rozack, A. (2018, June). Potensi zakat Rp 280 trilliun realisasi cuma 8 triliunan. Retrieved from https://radarsurabaya.jawapos.com

Saad, N., \& Abdullah, N. (2014). Is zakat capable of alleviating poverty? An analysis on the distribution of zakat fund in Malaysia. Journal of Islamic Economics, Banking and Finance, 113(3250), 1-27. doi: 10.12816/0025698

Sadili, M. (2003). Problematika Zakat Kontemporer. Jakarta: Penerbit FOZ.

Sari, D. F., Beik, I. S., \& Rindayati, W. (2019). Investigating the Impact of Zakat on Poverty Alleviation: A Case from West Sumatra, Indonesia. International Journal of Zakat, $4(2), 1-12$.

Seidman, I. (2019). Interviewing as Qualitative Research: A Guide for Researchers in Education and the Social Sciences (5th ed.). New York, NY: Teachers College Press. (23015121).

Setiawan, S. R. D. (2019, July 11). Potensi zakat di Indonesia sangat besar, tetapi.... Retrieved from Kompas.com website: https://money.kompas.com 
International Journal of Innovation, Creativity and Change. www.ijicc.net

Volume 15, Issue 3, 2021

Setyawardani, D. T. R., Paat, C. J., \& Lesawengen, L. (2020). Dampak bantuan PKH terhadap masyarakat miskin di kelurahan Bumi Nyiur kecamatan Wanea kota Manado. HOLISTIK: Journal of Social and Culture, 13(2), 1-14. Retrieved from https://ejournal.unsrat.ac.id/index.php/holistik/article/view/29324

Shaikh, S. A., \& Ismail, A. G. (2017). Role of zakat in sustainable development goals. International Journal of Zakat, 2(2), 1-9. doi: https://doi.org/10.37706/ijaz.v2i2.21

Sulaiman, M. (2003). The influence of riba and zakat on Islamic accounting. Indonesian Management and Accounting Review, 2(2), 149-167.

Susanti, R. (2019, November 5). Potensi Zakat di Indonesia Capai Rp 280 Triliun. Retrieved from KOMPAS.com website: https://regional.kompas.com/read/2019/11/05/14514051

Thalib, H., Irwan, M., \& Ro'is, I. (2017). Model pengelola zakat untuk mengatasi kemiskinan di kota Bima. Maqdis: Jurnal Kajian Ekonomi Islam, 2(1), 21-34. doi: 10.15548/maqdis.v2i1.76

Wahab, N. Abd., \& Rahman, A. R. A. (2011). A framework to analyse the efficiency and governance of zakāt institutions. Journal of Islämic Accounting and Business Research, 2(1), 43-62. doi: 10.1108/17590811111129508

Wicaksono, J. W. (2019). Distribusi Zakat Produktif untuk Pengembangan Ekonomi. Dinar : Jurnal Prodi Ekonomi Syariah, 2(1), 1-20. Retrieved from https://ejurnal.stail.ac.id/index.php/dinar/article/view/64

Wiradifa, R., \& Saharuddin, D. (2018). Strategi Pendistribusian Zakat, Infak, dan Sedekah (ZIS) di Badan Amil Zakat Nasional (BAZNAS) Kota Tangerang Selatan. Al-Tijary, $3(1), 1-18$. 